\title{
Public Functions, Private Markets: Credit Registration by Aldermen and Notaries in the Low Countries, 1500-1800
}

\section{Oscar Gelderblom, Mark Hup, and Joost Jonker}

\section{Introduction}

Well-organized financial systems are conducive to economic growth and development (Levine 1997; Sylla 2002), but the ways in which they do so vary greatly. Countries with similar performance often have very differently organized financial systems, and long-running debates about the respective merits of particular institutional configurations, say banks versus markets or the presumed advantages of Universalbanken, did not yield firm conclusions as to the economic superiority of one configuration over another (Sylla 1991; Fohlin 1999; Levine 2002; Rousseau and Sylly 2007; Carlos and Neal 2011; Calomiris and Haber 2014). The recent financial crisis has added a new dimension to these debates, however, some systems proving more resilient than others (e.g. Bordo et al. 2015).

O. Gelderblom $(\bowtie) \bullet$ J. Jonker

Universiteit Utrecht, Utrecht, Netherlands

M. Hup

UC Irvine, Irvine, CA, USA

(C) The Author(s) 2018 
Tracing the historical roots of today's financial systems is the obvious way to understand their respective differences, but only if we do not take the twentieth-century model outcome, big banks and flexible securities' markets financing modern economic growth, for granted. Important though it is to trace the evolution of, say, deposit banking and securities trading from late medieval Italy and Flanders via seventeenth-century Holland to eighteenth-century Britain, we need to put that evolution back into its historical context if we want to learn why the eventual outcome between countries differed. Merton and Bodie's (1995) functional analysis provides a very practical framework for doing this, because by analyzing how basic financial functions were performed in any given system, we get to know at the same time how the system worked, and what kind of opportunities and constraints the individual operators faced, in short, what determined the pattern of supply and demand which drove a particular system's evolution. Moreover, such a functional analysis is particularly useful for understanding early modern financial systems, because patterns of supply and demand were so very different. Most firms were financed directly, through family deposits, partnerships, suppliers' credit, or outside borrowing with bills. Moreover, there existed a large and diverse group of intermediaries, such as money changers, notaries, cashiers, attorneys, and town magistrates which in the end disappeared, but whose operations, to a greater or lesser degree, shaped a financial system's evolution.

In this chapter, we adopt the functional analysis framework for exploring the operations of two groups of such disappeared intermediaries in the Low Countries, notaries and aldermen. Drawing our inspiration from the pioneering work of Hoffman et al. (2000) on the Parisian notaries' extensive financial intermediation for private customers, we ask whether, in the Low Countries, officials with a similar position could also build and maintain what was essentially a banking business in all but name and, if not, why not. The Parisian notaries' commanding position as financial intermediaries rested on their ability to combine the positive externalities of their professional network with informational advantages from property transactions, the issuing of government debt, and managing clients' estates, thereby reducing information asymmetries between borrowers and lenders. 
In theory, notaries in the Low Countries could have developed similar informational advantages but their position in the market seems to have been quite different. When public notaries were first admitted as drafters of private contracts in the sixteenth century, cities already offered registration facilities for contracts such as annuities, mortgages, or debts arising from market or fair transactions (Soly 1974; Dambruyne 1988; Zuijderduijn 2009; Cappon 2005; Nève 2005). Moreover, local governments increasingly accepted business ledgers and privately written contracts as conclusive proof in court cases, which may have reduced the benefits of public registration (Gelderblom 2013; Van Bochove and Kole 2014).

To determine the function of notaries and aldermen in the financial system of the early modern Low Countries, we compiled a new database of almost 13,000 credit transactions registered by aldermen and notaries between 1500 and 1780 sampled at 40-year intervals from six cities: Amsterdam, Utrecht, Den Bosch, Leiden, Antwerp, and Ghent. The cities were chosen to reflect differences in political regime and economic conditions. Until the end of the sixteenth century, all six cities belonged to the Habsburg empire, but thereafter the four northern cities Amsterdam, Utrecht, Leiden, and, from 1628, Den Bosch became part of the Dutch Republic, whereas Ghent and Antwerp remained in the Spanish Habsburg empire. As for their economic position, Antwerp and Amsterdam were major international financial and trading hubs, while Ghent and Leiden were manufacturing cities.

The dataset serves four related aims in this chapter. First, we compare the volume of the credit transactions processed by aldermen and notaries in each city, looking at the number and value of registered loans. We also split the sample to see whether there were any differences between the contracts registered by aldermen and by the notaries. Then we compare the size of the markets which aldermen and notaries served with that of other credit markets within and outside the Low Countries. Finally, we use these loan characteristics in a multivariate regression analysis to measure how well different aspects of risk were priced in the markets served by aldermen and notaries. Taken together, the answers to these questions will allow us to establish whether notaries and aldermen merely acted passively when registering private loans, or became active intermediaries in local credit markets. 


\section{Registering Private Debt}

Low Countries town magistrates preceded notaries as administrators of credit transactions by several centuries. In all major cities in Flanders, Brabant, and Holland, the registration of private loans by the court of aldermen (schepenbank) can be traced back to the fourteenth century, if not earlier (Zuijderduijn 2009: 184-90; Van Bochove et al. 2015). The reason for this was the formal obligation for property owners to register loans secured on real estate with the local authorities. Initially, the loans took the form of annuities (renten), that is, mortgages on real estate, that were used by artisans and merchants to fund the initial purchase of a house or piece of land but also, for those already in possession of the premises, to free up capital for other investments, or to transfer assets to the next generation (Schnapper 1956). During the fourteenth century, urban governments followed suit by selling renten secured on future tax revenues. By 1500, every major town in the Habsburg Netherlands had become used to selling annuities to raise money, either for exceptional expenses such as rebuilding defenses in the face of war, or to meet the constantly rising fiscal demands of the Brussels government (Munro 2003; Boone et al. 2003; Van der Heijden 2006; Zuijderduijn 2009).

Besides renten, local governments registered other private loans as well. In Flanders as early as the twelfth century, the city of Ypres registered debts issuing from transactions at the local fairs (Des Marez 1901). By 1500, town officials across the Low Countries exercised their so-called voluntary jurisdiction, to allow their citizens to formalize debts issuing from the sales of sundry goods, house rentals, or labor services (Zuijderduijn 2009). These promissory notes went by a variety of names (schepenbrief, schepenkennis, plecht), but they shared two key characteristics. On the one hand, unlike annuities, both the debtor and the creditor could terminate the contract upon maturity (Schnapper 1956). On the other hand, the loan did not have to be secured on a specific piece of real estate. More often than not the parties agreed upon a so-called general mortgage, a formal claim on someone's person plus all his or her present and future possessions in the form of real estate or other goods (Van Bochove et al. 2015; Van Hoof 2015: 85-140). This turned the schepenkennissen into 
transferable claims not dissimilar to IOUs (promissory notes) circulated by businessmen in Antwerp and Amsterdam (Van Der Wee 1967; Gelderblom and Jonker 2004; Puttevils 2015a), but with the additional legal security of formal registration.

For the present chapter, we collected both the private annuities and schepenkennissen recorded by the aldermen of six cities: Ghent, Antwerp, Den Bosch, Utrecht, Leiden, and Amsterdam. However, unlike previous studies by Soly (1974, 1977), Dambruyne (1988, 2001), Hanus (2009), and others, we did not include annuities contracted between the buyer and seller of a specific piece of property with the sole purpose of funding that purchase. Though this was definitely a very large segment of the annuities market, these loans left debtors no choice as to the amount, purpose, or counterparty of the contract. ${ }^{1}$ In other words, we only collected private annuities which were functionally equivalent to the schepenkennissen or IOUs in allowing borrowers and lenders to set terms and conditions without any prior constraint. ${ }^{2}$ For the same reason, we excluded the so-called kustingen or kustingbrieven, that is, deferred payments of real estate, as often as not in three annual installments of equal size (Zuijderduijn 2008). ${ }^{3}$ Finally, we did not include any transfers of schepenkennissen or annuities because these did not constitute the creation of credit either. ${ }^{4}$

The aldermen's records from the six cities show their registration of private loans in full swing during the sixteenth century (Table 1). The officials of Antwerp and Ghent recorded hundreds of loans every year, with numbers in Den Bosch even higher because its aldermen also recorded debts contracted in a wide area surrounding the city. For Amsterdam and Leiden, no records survive for most of the sixteenth century, but the data we do have for the final quarter of the sixteenth century show these towns' officials very active as well. During the seventeenth and eighteenth centuries, the aldermen fared differently across cities. In Ghent, they virtually stopped recording private loans after 1600, and Utrecht, Den Bosch, and Leiden also saw a marked decline, especially during the eighteenth century. In Antwerp and Amsterdam, debt registration diminished as well, but notably in the latter the aldermen continued to register several hundred new loans per year. 
Table 1 The annual number of loans recorded by aldermen and notaries in six cities, 1500-1780

\begin{tabular}{lrrrrrrrr}
\hline ALDERMEN & 1500 & 1540 & 1580 & 1620 & 1660 & 1700 & 1740 & 1780 \\
Ghent & 748 & 499 & 112 & 105 & 56 & 13 & 1 & 20 \\
Antwerp(a) & 775 & 777 & 445 & 534 & 574 & 288 & 152 & 185 \\
Den Bosch & 972 & 955 & 211 & 485 & 170 & 273 & 80 & 29 \\
Utrecht & & 50 & 76 & 184 & 92 & 43 & 97 & 48 \\
Leiden & & & & 160 & 190 & 73 & 155 & 61 \\
Amsterdam (b) $^{(b)}$ & & & 83 & 640 & 807 & 320 & 490 & 476 \\
& 2,495 & 2,281 & 927 & 2,108 & 1,889 & 1,010 & 975 & 819 \\
NOTARIES & 1500 & 1540 & 1580 & 1620 & 1660 & 1700 & 1740 & 1780 \\
Ghent & & & & 7 & 257 & 437 & 302 & 444 \\
Antwerp & & 14 & 2 & 59 & 272 & 479 & 148 & 162 \\
Den Bosch & & & & & 31 & 125 & 128 & 216 \\
Utrecht & & & 3 & 9 & 64 & 81 & 93 & 193 \\
Leiden & & & 6 & 58 & 636 & 79 & 47 & 44 \\
Amsterdam & & & & 52 & 354 & 176 & 386 & 239 \\
& & 14 & 11 & 185 & 1,614 & 1,377 & 1,104 & 1,298 \\
\hline
\end{tabular}

Source: EURYI-VIDI database. https://doi.org/10.24416/UU01-7UC5BL aExtrapolated from samples of the city's schepenregisters: 1500 (45.8\%), 1540

$(34.1 \%), 1580(21.1 \%), 1620(29.4 \%), 1660(40.4 \%), 1700(45.5 \%), 1740$ (53.9\%), $1780(26.0 \%)$

${ }^{\mathrm{b}} \mathrm{B}$ ased on all contracts recorded in the city's rentenboeken from 1580 onward, plus, from 1620 onward, a $20 \%$ sample of the schepenkennissen

These general trends are reflected in the value of the loans registered by the aldermen (Table 2). Amsterdam stands out with annual loan values between 1 and 1.5 million guilders in the eighteenth century, with Antwerp a distant second with total amounts of between 400,000 and 800,000 guilders during the seventeenth century. In that same period, loans recorded by the aldermen of Den Bosch and Leiden peaked at 200,000 guilders in 1620 and 1660, respectively. These very different totals were obviously related to the size of the population. To correct for this, we can divide the total sums by the number of inhabitants. Measured per capita, the first thing to notice are the very low loan values: never more than 10 or 15 guilders, the level reached by the aldermen of Antwerp and Den Bosch in the seventeenth century. Equally striking is the persistently low value of recorded loans in Ghent, less than 1.50 guilders per capita, throughout the early modern period. In the eighteenth century, the other cities reached similarly low levels, except for Amsterdam, where aldermen remained as active as they had been since the middle of the seventeenth century. 


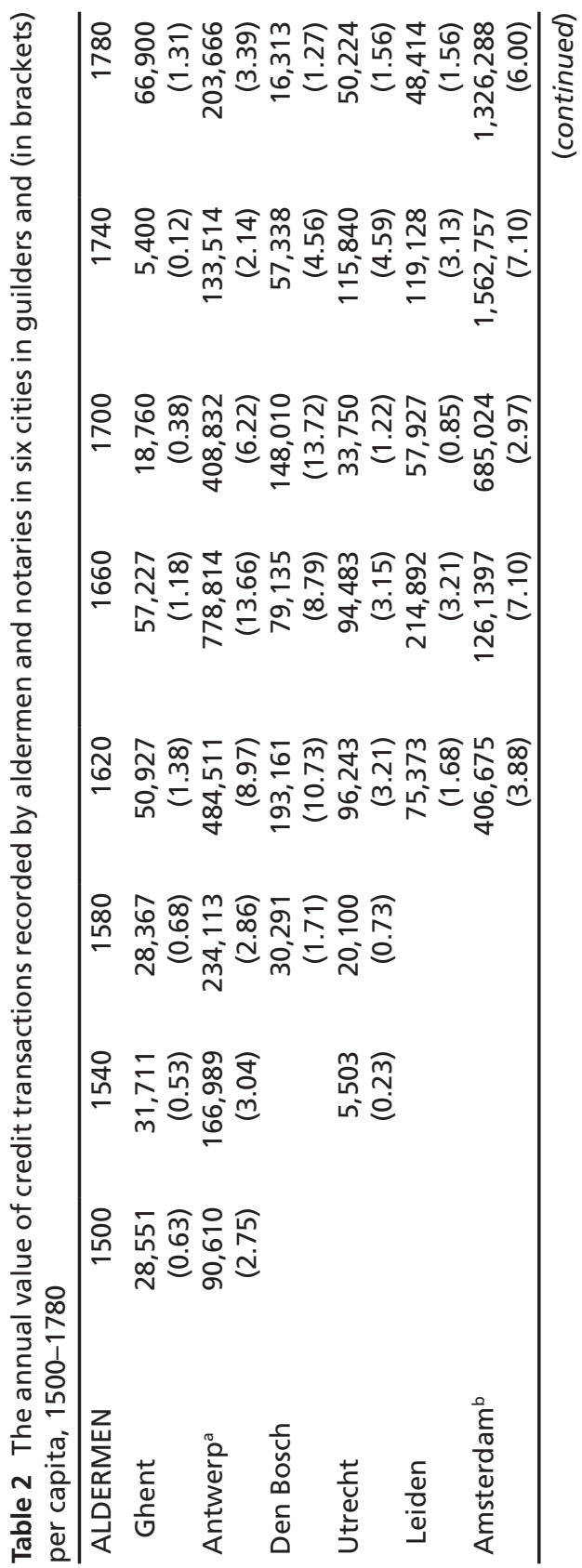




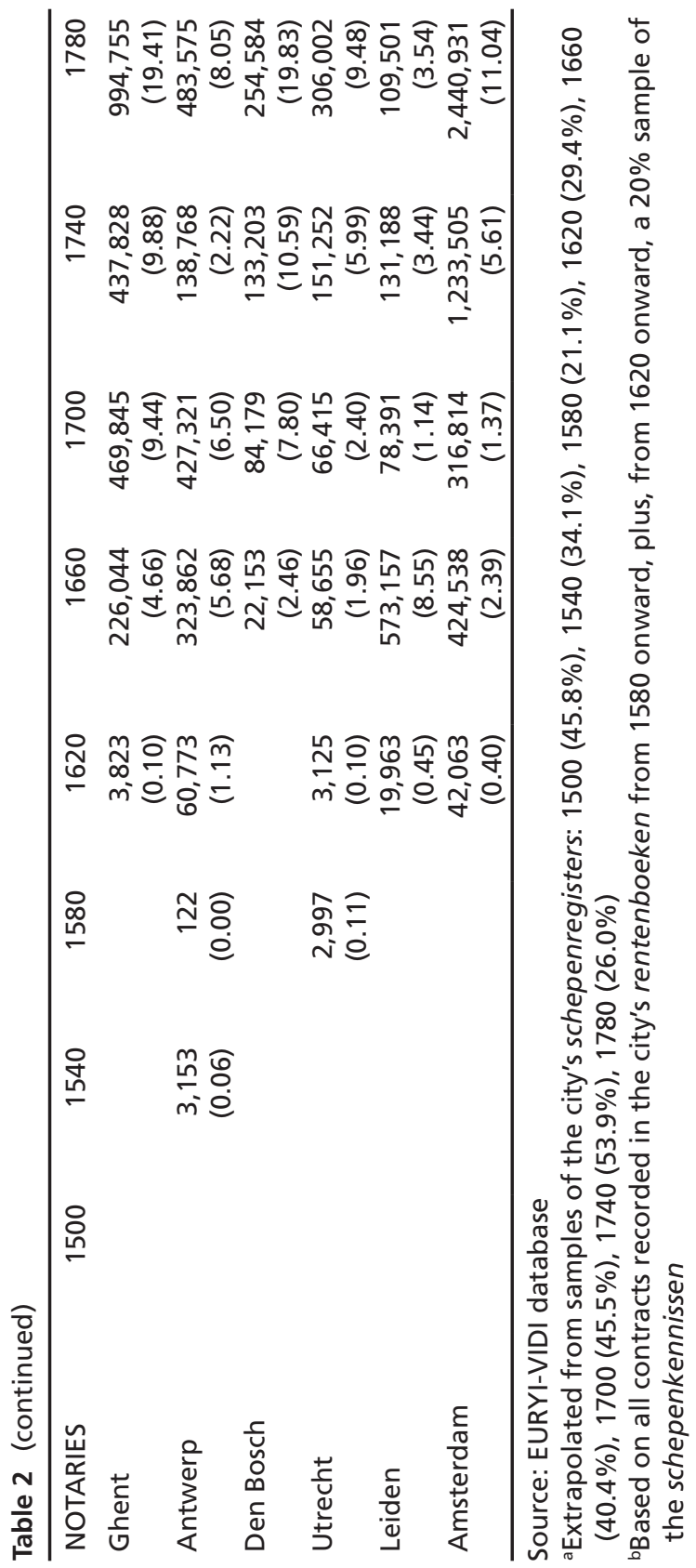


One explanation for this divergent development would be the more or less successful entry of notaries as drafters of private loan contracts. ${ }^{5}$ Ordinances issued by Charles V during the 1530s raised their existing private practice of drafting formal legal documents into a public office. As a result, notarial contracts obtained the same legal status as those drawn up by aldermen, provided notaries kept registers with copies of all deeds signed in their offices. This opened the way for notaries to develop into a legal service provider offering a full range of contracts, including last wills and testaments, marriage contracts, business partnerships, shipping contracts, property transactions, and selling assets such as annuities (Gelderblom 2013: 87-94). To determine whether they built on this business to become financial intermediaries as well, we collected the private loans they recorded in the six cities between 1540 and 1780 .

Before the middle of the seventeenth century, we found very few debt contracts in the notarial protocols (Table 1). In 1620, there are less than 200 contracts in the six cities, against 2,100 for the aldermen. But in 1660, the notaries, with 1,600 contracts, were almost at a par with the aldermen total of 1,900 contracts. The notaries' share continued to grow in later years, but even in 1780 the aldermen in the six cities combined still recorded one third of all loans. This persistence is partially caused by the inclusion of Amsterdam in our sample, as the aldermen of the Dutch port registered twice as many loans per year as the notaries in 1780. In all the other cities, the notaries had clearly replaced the aldermen as the principal officials for registering private debt. This shifting balance is also reflected in the value of loans registered by notaries and aldermen (Table 3). As early as 1660, notaries processed $80 \%$ of loan totals in Ghent, just under three quarters in Leiden, and some $40 \%$ in Utrecht (Table 3). In the other three cities, they handled between a fifth and one third of the all debt. In the eighteenth century, the share of the notaries increased across the board and the differences between cities fell. Still, in 1780 notaries in Leiden, Antwerp, and Amsterdam were responsible for only $70 \%$ of the value of all registered loans.

Now the question is why did the public registration of private loans in the Low Countries gradually shift from the aldermen to the notaries. Only the Ghent case has a clear cut answer. A feudal relic gave local landlords the right to keep their own administration of property transfers and related credit transactions, without obligation to register them with the 
Table 3 The notaries' share in total loan amounts, $1500-1780$ (\% of total)

$\begin{array}{lllllll}1540 & 1580 & 1620 & 1660 & 1700 & 1740 & 1780\end{array}$

\begin{tabular}{|c|c|c|c|c|c|c|c|}
\hline Ghent & 0.0 & 0.0 & 7.0 & 79.8 & 96.2 & 98.8 & 93.7 \\
\hline Antwerp & 1.9 & 0.1 & 11.1 & 29.4 & 51.1 & 51.0 & 70.4 \\
\hline Den Bosch & & 0.0 & 0.0 & 21.9 & 36.3 & 69.9 & 94.0 \\
\hline Utrecht & 0.0 & 13.0 & 3.1 & 38.3 & 66.3 & 56.6 & 85.9 \\
\hline Leiden & & 0.0 & 20.9 & 72.7 & 57.5 & 52.4 & 69.3 \\
\hline Amsterdam & & & 9.4 & 25.2 & 31.6 & 44.1 & 64.8 \\
\hline
\end{tabular}

Source: EURYI-VIDI database

Note: Darker coloring indicates relatively high percentage

aldermen. Consequently, notaries were able to develop a practice in providing a service that hardly existed before (Van Bochove et al. 2015). This formed very much an exception. Elsewhere, the operations of aldermen and notaries often overlapped. In Antwerp and Den Bosch, notaries were formally required to take turns as clerks at city hall, but they kept separate registers for the city and for their own practice. In the other three cities, notaries sometimes acted as town secretaries as well, but not on a regular basis. As a rule, aldermen and notaries kept separate offices, so their function in the local financial market may have differed accordingly. To find out how their respective functions developed, we look more closely at the transactions in our sample.

\section{Transaction Patterns}

Local credit markets in the early modern period were segmented by the use of different kinds of loan collateral. At least until the end of the sixteenth century, real estate was the most important store of wealth for people living in towns. As urban governments wanted to keep track of the 
ownership of this property, anybody who wanted to use a house or a piece of land to secure a loan ended up registering this loan with the aldermen. In fact, the annuities (renten) sold for this purpose were themselves considered real property, and while borrowers had the right to repay these loans, creditors who wanted their money back had to sell the annuity to somebody else-once again a transaction that required formal registration at the town hall. Thus, as long as borrowers and lenders valued these specific terms, the aldermen were indispensable as loan administrators. The number of annuities recorded in the six cities declined, however, from 6 per 1000 inhabitants at the beginning of the sixteenth century to less than 1 per 1000 in the eighteenth century (Figure 1).

This movement away from losrenten and lijfrenten as the preferred credit instrument coincided with the emergence of a new type of collateral, the general mortgage, which allowed creditors to seize any part of a debtor's property in case of default. First applied as an additional safeguard for annuities in the fifteenth century, the general mortgage was increasingly used as the sole guarantee for loans. This is clearly visible in Table 4, which summarizes our knowledge of the collateral of 10,065 loans $(83.7 \%$ of the total) registered by aldermen and notaries in the Low Countries. ${ }^{6}$ More

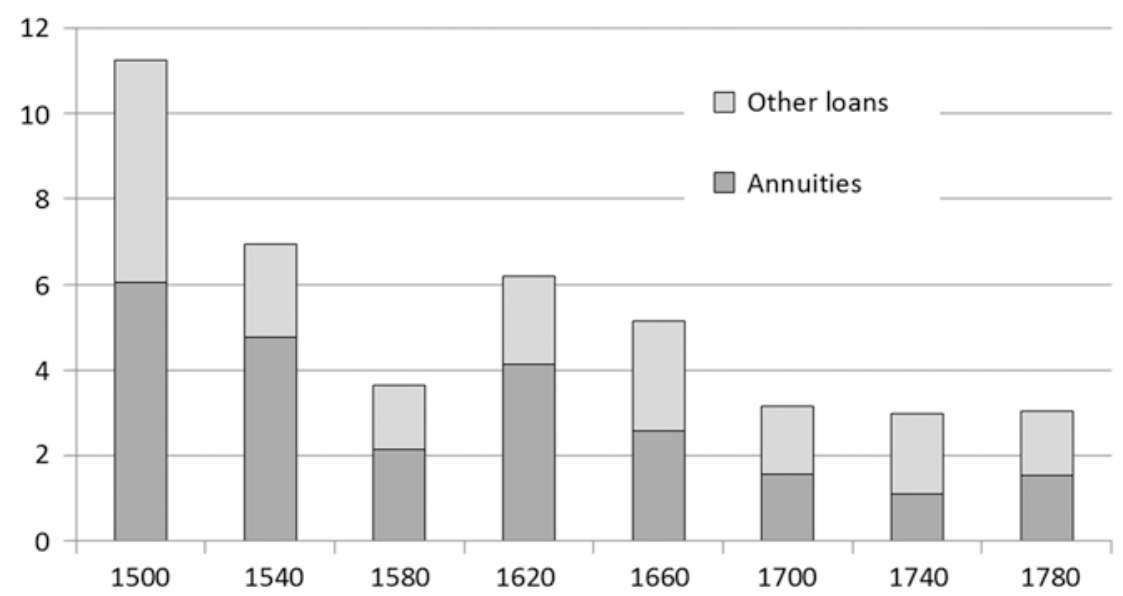

Fig. 1 Estimated number of annuities and other loans per 1000 inhabitants recorded by aldermen in six cities (1500-1780) (Source: EURYI/VIDI database; extrapolation based on sampling for Amsterdam and Antwerp; the graph includes credit transactions recorded by Ghent notaries between 1620 and 1780) 
Table 4 The collateral of loans recorded by aldermen and notaries, 1500-1780

\begin{tabular}{lrrrrrrrr}
\hline \multirow{2}{*}{$\begin{array}{l}\text { Collateral } \\
\text { type }\end{array}$} & \multicolumn{2}{c}{ Aldermen } & \multicolumn{2}{c}{ Aldermen } & Notaries Ghent & \multicolumn{2}{r}{ Other notaries } \\
\cline { 2 - 9 } & \multicolumn{2}{c}{ Annuities } & \multicolumn{2}{c}{ Other loans } & \multicolumn{2}{c}{ All loans } & \multicolumn{2}{c}{ All loans } \\
\hline Special mortgage & 1,241 & $49.0 \%$ & 179 & $7.4 \%$ & 117 & $8.3 \%$ & 510 & $13.4 \%$ \\
$\quad$ Real estate & 1,177 & $46.5 \%$ & 113 & $4.7 \%$ & 25 & $1.8 \%$ & 81 & $2.1 \%$ \\
$\quad$ Financial assets & 25 & $1.0 \%$ & 6 & $0.2 \%$ & 11 & $0.8 \%$ & 209 & $5.5 \%$ \\
$\quad$ Other & 39 & $1.5 \%$ & 60 & $2.5 \%$ & 81 & $5.7 \%$ & 220 & $5.8 \%$ \\
Special + general & 833 & $32.9 \%$ & 826 & $34.0 \%$ & 733 & $52.0 \%$ & 470 & $12.3 \%$ \\
$\quad$ mortgage & & & & & & & & \\
$\quad$ Real estate & 787 & $31.2 \%$ & 632 & $26.2 \%$ & 625 & $44.4 \%$ & 267 & $7.0 \%$ \\
$\quad$ Financial assets & 22 & $0.9 \%$ & 24 & $1.0 \%$ & 87 & $6.2 \%$ & 135 & $3.5 \%$ \\
$\quad$ Othera & 24 & $1.0 \%$ & 170 & $7.0 \%$ & 21 & $1.5 \%$ & 68 & $1.8 \%$ \\
General mortgage & 457 & $18.1 \%$ & 1,421 & $58.6 \%$ & 559 & $39.7 \%$ & 2,831 & $74.3 \%$ \\
ALL CONTRACTS & 2,531 & 100 & 2,426 & 100 & 1,409 & 100 & 3,811 & 100 \\
\hline
\end{tabular}

Source: EURYI/VIDI database

ancludes loans with a combination of assets (real, financial, other) as collateral

than three quarters of the annuities (losrenten, liffrenten) registered at the town hall came with a specific piece of real estate as collateral, as often as not in combination with a general mortgage. Conversely, three quarters of the loans recorded by notaries specified no other collateral than the person and goods of the borrowers. The specific collateral pledged for the remaining quarter consisted not only of real estate but also of financial assets. The one exception is the notaries in Ghent, who, as noted, performed services provided by town clerks elsewhere. The vast majority of the loans they recorded were indeed collateralized on a general mortgage, but half of them also specified real estate as collateral, mirroring the notaries' involvement in two distinct market segments.

But even if borrowers and lenders turned away from annuities, they kept coming to the aldermen for the registration of other private loans (Figure 1). Admittedly, the number of recorded contracts was modest in most cities, but especially in Antwerp in the sixteenth century, and in Amsterdam in the seventeenth and eighteenth centuries, several hundreds of loans were registered every year. The collateral pledged for these plechten, schepenkennissen, and schuldbekentenissen resembled that of the notarial loans: a general mortgage, sometimes with an additional pledge of real estate as collateral. One possible explanation for this persistent involvement of the aldermen could be the social background of the borrowers and lenders who used their services. As various historians have shown for 
the cities of Flanders and Brabant in the sixteenth century, craftsmen were the principal sellers of annuities, with a mixed group of retailers and wholesalers a distant second. Their creditors issued from broader shifts of society, including craftsmen, traders, civil servants, clergy, and a substantial group of widows and (the guardians of) orphans.

Our sample gives us the professions of some 2,000 borrowers and 3,000 lenders. These data, summarized in Table 5, suggest that the aldermen in other parts of the Low Countries served a clientele similar to that in Antwerp in the sixteenth century. Craftsmen and laborers make up $60 \%$ of the debtors with known profession, with traders a distant second at $25 \% .^{7}$ The craftsmen and laborers were much less dominant among the creditors which comprised a much broader group of artisans, traders, and public officials. If we then look at the professional background of debtors and creditors appearing before notaries between 1660 and 1780, it turns out that these officials had an equally broad customer base. Traders and public officials together accounted for half the loans, but craftsmen and laborers still took up about a third of all notarial credit. Only the creditors issued almost exclusively from higher social groups, with traders, public officials, noblemen, and clergy signing more than $85 \%$ of the loans.

Table 5 Professions of debtors and creditors in loans recorded by aldermen and notaries in six cities, $1500-1780$

\begin{tabular}{lrrrr}
\hline & & $1500-1620$ & $1660-1780$ \\
\hline Panel A. Debtors & $\begin{array}{r}\text { Aldermen } \\
(n=1,072)\end{array}$ & $\begin{array}{r}\text { Notaries } \\
(n=80)\end{array}$ & $\begin{array}{r}\text { Aldermen } \\
(n=493)\end{array}$ & $\begin{array}{r}\text { Notaries } \\
(n=2,085)\end{array}$ \\
Craftsmen and laborers & $61.5 \%$ & $45.0 \%$ & $58.4 \%$ & $34.2 \%$ \\
Traders & $27.7 \%$ & $38.8 \%$ & $22.7 \%$ & $30.7 \%$ \\
Public officials and civil servants & $4.1 \%$ & $6.3 \%$ & $11.6 \%$ & $19.1 \%$ \\
Nobility and clergy & $3.5 \%$ & $3.8 \%$ & $5.1 \%$ & $8.8 \%$ \\
Other & $3.3 \%$ & $6.3 \%$ & $2.2 \%$ & $7.2 \%$ \\
& & & & \\
Panel B. Creditors & Aldermen & Notaries & Aldermen & Notaries \\
& $(n=994)$ & $(n=75)$ & $(n=399)$ & $(n=1,661)$ \\
Craftsmen and laborers & $36.3 \%$ & $21.3 \%$ & $19.3 \%$ & $12.3 \%$ \\
Traders & $25.5 \%$ & $62.7 \%$ & $24.3 \%$ & $35.8 \%$ \\
Public officials and civil servants & $14.0 \%$ & $12.0 \%$ & $41.9 \%$ & $31.7 \%$ \\
Nobility and clergy & $10.5 \%$ & $2.7 \%$ & $14.0 \%$ & $17.3 \%$ \\
Other & $13.8 \%$ & $1.3 \%$ & $0.5 \%$ & $2.8 \%$ \\
\hline
\end{tabular}

Source: EURYI-VIDI database 
With both market segments accessible to those higher social groups, there must be another explanation for the growing share of notaries in the public registration of private loans. Differences in the average and median loan amounts recorded by notaries and aldermen offer a partial answer. As Table 6 shows, the higher these amounts, the more likely it was that people went to a notarial office rather than the aldermen's bench. By 1780 , the average amount of loans processed by notaries was double the aldermen's average. One obvious reason was the higher number of merchants among the notaries' clientele, but if we compare average to median loan amounts (reported in Table 7), a more subtle difference between the two segments emerges. While median loan amounts remained largely similar, the averages diverged especially in the eighteenth century when notaries started to register some very large loans.

Table 6 The average size of loans recorded by aldermen and notaries in six cities (in guilders), $1500-1780$

\begin{tabular}{lrrrrrrrr}
\hline ALDERMEN & 1500 & 1540 & 1580 & 1620 & 1660 & 1700 & 1740 & 1780 \\
Ghent & 38 & 64 & 253 & 485 & 1,022 & 1,433 & $5,400^{\mathrm{a}}$ & 3,345 \\
Antwerp & 117 & 215 & 526 & 907 & 1,357 & 1,420 & 878 & 1,101 \\
Den Bosch & & & 144 & 398 & 466 & 542 & 717 & 563 \\
Utrecht & & 110 & 264 & 523 & 1,027 & 785 & 1,194 & 1,046 \\
Leiden & & & & 471 & 1,131 & 794 & 769 & 794 \\
Amsterdamc & & & & 635 & 1,563 & 2,141 & 3,189 & 2,786 \\
ALL CITIES & 48 & 90 & 338 & 620 & 1,316 & 1,339 & 2,045 & 2,090 \\
& & & & & & & & \\
NOTARIES & 1500 & 1540 & 1580 & 1620 & 1660 & 1700 & 1740 & 1780 \\
Ghent & & & & 546 & 880 & 1,075 & 1,450 & 2,240 \\
Antwerp & & 225 & 61 & 1,030 & 1,191 & 892 & 938 & 2,985 \\
Den Bosch & & & & & 715 & 673 & 1,041 & 1,179 \\
Utrecht & & & 999 & 347 & 916 & 820 & 1,626 & 1,586 \\
Leiden & & & 171 & 344 & 901 & 992 & 2,791 & 2,489 \\
Amsterdam & & & & 809 & 1,199 & 1.8 & 3,196 & 10,213 \\
ALL CITIES & & 225 & 284 & 701 & 1,009 & 1,048 & 2,016 & 3,536 \\
\hline
\end{tabular}

Source: EURYI-VIDI database

${ }^{a}$ Ghent 1740 is only one observation

${ }^{b}$ Extrapolated from samples of the city's schepenregisters: 1500 (45.8\%), 1540

(34.1\%), $1580(21.1 \%), 1620(29.4 \%), 1660(40.4 \%), 1700$ (45.5\%), 1740

(53.9\%), $1780(26.0 \%)$

'Based on all contracts recorded in the city's rentenboeken from 1580 onward, plus, from 1620 onward, a $20 \%$ sample of the schepenkennissen 
Table 7 Median loan amounts recorded by aldermen and notaries, 1500-1780

\begin{tabular}{lrrrrrrrr}
\hline ALDERMEN & 1500 & 1540 & 1580 & 1620 & 1660 & 1700 & 1740 & 1780 \\
Ghent $^{\mathrm{a}}$ & 25 & 143 & 120 & 288 & 700 & 900 & 5,400 & 1,800 \\
Antwerp & 72 & 128 & 203 & 562 & 671 & 900 & 600 & 850 \\
Den Bosch & & & 100 & 150 & 262 & 300 & 538 & 380 \\
Utrecht & & 63 & 184 & 400 & 700 & 500 & 1,000 & 600 \\
Leiden & & & & 300 & 800 & 500 & 500 & 500 \\
Amsterdam & & & & 320 & 1,040 & 1,300 & 2,200 & 2,000 \\
& 1500 & 1540 & 1580 & 1620 & 1660 & 1700 & 1740 & 1780 \\
NOTARIES & & & & 288 & 480 & 600 & 900 & 1,200 \\
Ghent & & 84 & 61 & 274 & 330 & 300 & 400 & 600 \\
Antwerp & & & & & 250 & 300 & 400 & 600 \\
Den Bosch & & & 372 & 177 & 323 & 600 & 550 & 800 \\
Utrecht & & & 156 & 239 & 500 & 500 & 1,400 & 1,000 \\
Leiden & & & & 500 & 600 & 855 & 1,300 & 2,500 \\
Amsterdam & & & & & & & & \\
\hline
\end{tabular}

Source: EURYI/VIDI database

${ }^{\text {a Ghent }} 1740$ is only one observation

If average and median amounts rose across the board, then small loans became more and more exceptional. In 1620, every third loan registered amounted to less than 200 guilders. Forty years later, it was only 1 out of 6 loans, and in the eighteenth century this share fell further to 1 out of 20 . Loans of less than 100 guilders virtually disappeared in the eighteenth century. ${ }^{8}$ In 1620 , the median amount was just over half to one-and-a-half a skilled artisan's annual wage of 200 guilders, but that rose to more than 2.5 times by 1660,4 times by 1740, and 5 times by 1780 . Presumably over time, people needing small loans found other ways to borrow, avoiding the formalities and cost of contracting before magistrates or notaries. The same was true for loans of short duration. We know loan maturities for about a third of all transactions. As Table 8 shows, up to 1,700 loans averaged about 2 years, but with a median of only a year, so a considerable number of contracts had either a much shorter or a rather longer maturity. During the eighteenth century, maturities doubled to four years while the difference between average and median, that is, the extreme maturities, dropped considerably. By all looks, the transactions in our sample evolved into a sort of standard longer-term loan, most noticeably so for the aldermen contracts with average maturities of 7 years by 1780 , against 3 for the notaries. 
As a further gauge of the differences between the two segments, we can probe loan purposes but again with a strong proviso since two-thirds of all contracts sampled come into the category other and unknown (Table 9). The stated loan purposes did not differ that much between the two service providers, save for the fact that the notaries processed rather more contracts with borrowers stating cash-in-hand as purpose. ' These cash loans were functionally equivalent to the private loans merchants and other businessmen could obtain on the money markets of Antwerp and Amsterdam. In addition to this standard form, notaries and aldermen also recorded loans that issued from specific business transactions,

Table 8 The maturity of loans recorded by aldermen and notaries in six cities (months), 1500-1780

\begin{tabular}{lrrrrrrrr}
\hline Average & 23 & 20 & 26 & 30 & 24 & 23 & 45 & 50 \\
Median & 12 & 10 & 12 & 12 & 12 & 12 & 36 & 48 \\
$\mathrm{~N}$ & 605 & 334 & 61 & 209 & 885 & 796 & 763 & 542 \\
ALDERMEN & & & & & & & & \\
Average & 23 & 20 & 27 & 38 & 29 & 31 & 70 & 85 \\
Median & 12 & 10.5 & 12 & 24 & 24 & 36 & 72 & 72 \\
$\mathrm{~N}$ & 605 & 324 & 59 & 146 & 379 & 177 & 241 & 156 \\
NOTARIES & & & & & & & & \\
Average & & & & & & & & \\
Median & & 28 & 11 & 13 & 21 & 21 & 33 & 36 \\
$\mathrm{~N}$ & & 10 & 11 & 11 & 12 & 12 & 18 & 24 \\
TOTAL & 1500 & 1540 & 1580 & 1620 & 1660 & 1700 & 1740 & 1780 \\
\hline
\end{tabular}

Source: EURYI/VIDI database

Table 9 The loan purpose recorded by aldermen and notaries in six cities, $1500-1780$

\begin{tabular}{lrrrrrrrr}
\hline Loan purpose & \multicolumn{2}{c}{ Aldermen } & \multicolumn{2}{c}{ Aldermen } & Notaries & \multicolumn{2}{r}{ Notaries } \\
\hline & Nr. of loans & Value of loans & Nr. of loans & \multicolumn{2}{c}{ Value of loans } \\
\hline Business use & 629 & $29 \%$ & 190,317 & $15 \%$ & 651 & $24 \%$ & $1,269,560$ & $26 \%$ \\
Cash-in-hand & 742 & $35 \%$ & 688,911 & $54 \%$ & 1,508 & $55 \%$ & $1,861,647$ & $38 \%$ \\
Real estate & 163 & $8 \%$ & 162,326 & $13 \%$ & 70 & $3 \%$ & 113,237 & $2 \%$ \\
Refinancing & 256 & $12 \%$ & 184,559 & $14 \%$ & 267 & $10 \%$ & $1,035,616$ & $21 \%$ \\
Other & 351 & $16 \%$ & 54,067 & $4 \%$ & 223 & $8 \%$ & 680,259 & $14 \%$ \\
Total & 2,141 & $100 \%$ & $1,280,180$ & $100 \%$ & 2,719 & $100 \%$ & $4,960,319$ & $100 \%$ \\
\hline
\end{tabular}

Source: EURYI/VIDI database 
Table 10 Credit transactions between parties of different gender, profession, and/or residence, $1500-1780$

\begin{tabular}{lrrrr}
\hline & \multicolumn{2}{l}{$\begin{array}{l}\text { Contracts with information } \\
\text { on both parties }\end{array}$} & \multicolumn{2}{l}{$\begin{array}{l}\text { Contracts in which } \\
\text { parties differ }(\%)\end{array}$} \\
\hline GENDER & & & & \\
$\begin{array}{l}\text { Aldermen } \\
\text { Notaries }\end{array}$ & 5,111 & $(79.59 \%)$ & 1,383 & $(27.1 \%)$ \\
$\begin{array}{l}\text { PROFESSION } \\
\text { Aldermen }\end{array}$ & 5,319 & $(94.9 \%)$ & 1,614 & $(30.3 \%)$ \\
$\begin{array}{l}\text { Notaries } \\
\text { RESIDENCE }\end{array}$ & 547 & $(8.52 \%)$ & 308 & $(56.3 \%)$ \\
$\begin{array}{l}\text { Aldermen } \\
\text { Notaries }\end{array}$ & 841 & $(15.01 \%)$ & 504 & $(59.9 \%)$ \\
\hline
\end{tabular}

Source: EURYI-VIDI database

whether sales, investments, or repairs. In many of these cases, the sole purpose of registration was to create a formal record of already existing financial claims.

It is difficult to tell why some loans were registered with a notary or alderman, while others were merely recorded in private. But we do find differences between borrowers and lenders that may have spurred formal registration (Table 10). For instance, $25-30 \%$ of the publicly recorded loans were between men and women, or rather widows in many cases. ${ }^{10}$ We also observe differences when the aldermen and notaries recorded the residence and occupation of borrowers and lenders. In these cases, the two parties held different jobs in three out of four contracts, and they lived in different places about one third of the time. These ratios were similar for aldermen and notaries, but the latter recorded the residence and profession of both parties more frequently. This suggests that, while both officials offered legal security to borrowers and lenders, parties who did not know each other well were somewhat more likely to turn to a notary.

\section{The Functions of Aldermen and Notaries}

Our data show that aldermen and notaries in the Low Countries served partially overlapping market segments, with the formal, public registration of loans as the common denominator. In terms of Merton and Bodie's functional approach to financial markets, the aldermen and notaries 
helped debtors and creditors to overcome incentive problems (function 6). The public registration of a loan's terms and conditions made for easy enforcement with the added advantage of a priority claim in case of liquidation of the debtor's estate. ${ }^{11}$ Now the question is, whether the aldermen and notaries in the Low Countries built on this administrative role to perform additional functions as well, in particular the ones highlighted by Hoffman et al. in their work on Parisian notaries, that is, the transfer of funds from savers and investors to borrowers (function 3) and the allocation of these loans according to the perceived default risk of the debtors (function 4). ${ }^{12}$

To answer this question, we first need to establish how important the registration of loans by notaries and aldermen was in comparison to other segments of the market. We know that some Antwerp merchants during the sixteenth century, and some of their Amsterdam colleagues a century later, possessed commercial paper worth tens of thousands of guilders, but we have no idea of how much of that paper circulated (Gelderblom and Jonker 2004; Puttevils 2015a, Gelderblom et al. 2016). Nor do we know more about bills of exchange or suppliers' credit, apart from the fact that it was very widely used. The only gauge we have is the issue of public debt by the sovereign province of Holland, the single biggest issuer in the Low Countries during the seventeenth and eighteenth centuries. From a creditor's viewpoint, this is not such a bad gauge. Formally, Holland bills had a maturity of 6-12 months, though most if not all were habitually rolled over to become de facto consolidated debt (Gelderblom and Jonker 2011). As often as not the contracts that interest us had a maturity of some 18 months across all cities, with an average of 24-30 months and a median of 12 during the seventeenth century, rising to $45-50$ and 36-48, respectively, during the eighteenth century.

Because there are no comparable figures for public debt issues in the provinces Flanders, Brabant, and Utrecht, we can only draw a comparison for the two Holland cities in our sample, Leiden and Amsterdam, for the five benchmark years between 1620 and 1780. Provincial debt was issued by the local tax receivers, each in proportion to their share in total tax receipts. Consequently, the receivers in Leiden and Amsterdam together sold about $35 \%$ of each new loan. Elsewhere, we have reconstructed detailed, annual figures for Holland's total debt, repayments and new 
issues (Gelderblom and Jonker 2011). Figure 2 compares the value of $35 \%$ of those new issues with the amount of debt processed by aldermen and notaries during the benchmark years. Our comparison makes the volume of private debt stand out as very substantial: in each of the benchmark years, aldermen and notaries processed higher amounts than the tax receivers issued in public debt. If the volume of private debt outstripped public debt issues in most years, we may also assume the reverse to have been true. The comparatively low figure for Amsterdam in 1700, about half of that in 1660,1740, and 1780, could then be explained by strong public demand during the preceding Nine Years' War.

Thus, measured by the value of the loans they recorded, notaries and aldermen handled a substantial volume of debt. But was this enough to evolve into credit intermediaries in the way Parisian notaries did? To put the numbers for the Low Countries in perspective, we can compare our data for 1740 and 1780 with similar data collected by Hoffman et al. (2000) for Paris and other French cities. Table 11 reports the number of new loans per 1000 inhabitants in 1740 and 1780. In both years, the difference between France and the Low Countries is considerable, with notaries in French cities recording between 10 and 16 contracts per 1000 inhabitants, against 1 to 3 contracts in Antwerp, Leiden, and Amsterdam. Only in Den Bosch were the notaries as active as their French counterparts, while Utrecht (in 1740) and Ghent are somewhere in

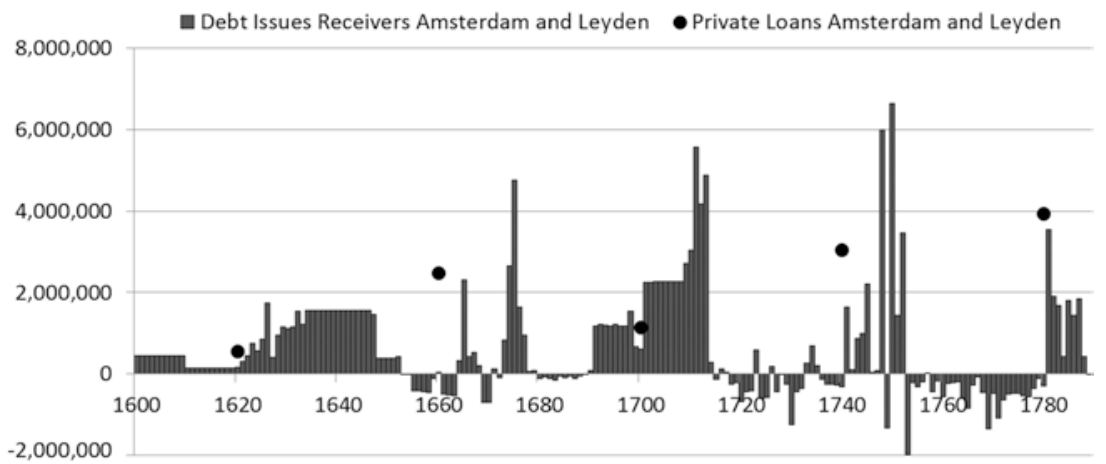

Fig. 2 Public debt issues and private loans recorded by aldermen and notaries in Leiden and Amsterdam, 1600-1780 (Source: EURYI/VIDI database and Gelderblom and Jonker 2011) 
between. The loans recorded by aldermen in the Low Countries did not make up for the difference, as they hovered between one and four per 1000 inhabitants in each of the six cities.

Following the lead of Hoffman et al. (2000), we can also use the stated maturity of loans to derive the stock of credit in benchmark years. Aldermen and notaries did not always record the maturity or the actual extinction of debts, but for Antwerp, Leiden, and Amsterdam, we have sufficient data to permit a rough estimate of the value of loans outstanding. Figure 3 reports this stock of debt per capita for the years 1740 and 1780. The difference between Paris and all the other cities is huge. As a result of its larger population - three times the size of that of Amsterdamand the much longer loan maturity, the stock of notarized loans in Paris in 1740 was almost ten times bigger than the loans of aldermen and notaries combined in Amsterdam and Leiden, with Antwerp lagging even further behind. Forty years later, the gap was larger still, with the Parisian stock of loans per capita 14 times larger than in Antwerp and Amsterdam. Paris was clearly exceptional, but even in other big cities in France (with 60,000

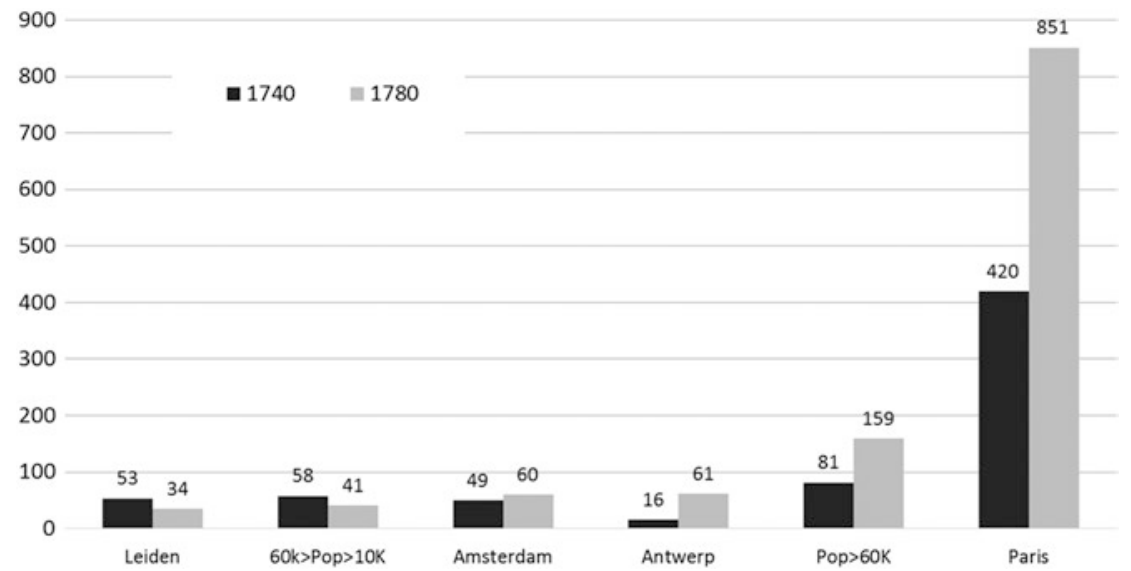

Fig. 3 Per capita stock of debt recorded by notaries in France and by notaries and aldermen in the LOW COUNTRIES in 1740 and 1780 (guilders) (Source: EURYI-VIDI database; Data for Paris, Philip T Hoffman, Gilles Postel-Vinay and Jean-Laurent Rosenthal, "Priceless Markets II: Time and Space", unpublished mimeo. One livre is $4.45 \mathrm{gram}$ of silver. One guilder is $9.61 \mathrm{gram}$ of silver) 
or more inhabitants) the stock of notarial loans in 1780 was over twice the size of that recorded by aldermen and notaries in Antwerp and Amsterdam.

In other words, the credit processed by aldermen and notaries in the Low Countries, though substantial in itself compared to what the public debt absorbed, was far less important in the eighteenth century than notarial credit was in Paris, or other major French cities. Consequently, the aldermen and notaries did not evolve into credit intermediaries in the way Parisian notaries did. One reason was that neither one could capitalize on informational advantages. With the exception of Ghent, all transactions pertaining to real estate had to be publicly registered by the aldermen's bench, rendering information about such transactions essentially free. Conversely, that publicity may explain why, over time, contracting parties came to use notaries rather than aldermen, especially when transacting large sums with collateral other than real estate: notarial contracts remained confidential.

Notaries, however, did not occupy a central position in the business world. Merchants in major commercial cities used notaries only sparingly. In Amsterdam, and probably elsewhere, too, bills of exchange generated a steady stream of notarized protests, because local custom required such documents to start proceedings for non-payment. But the initial bills were never notarized. Merchants initially, that is to say during the last quarter of the sixteenth century, used notarized shipping contracts, but as shipping grew and contracts standardized, they switched to private contracting and used notaries only as an exception, for trips with unusual cargoes, partners, or destinations (Gelderblom 2013). The securities trade showed a similar switch from notarized to private contracting (Petram 2014). The use of affidavits or solemn depositions taken by notaries also appears to have dropped over time as merchants found other cheaper ways of giving formal testimony in business disputes.

Because of the formalities involved, registered contracts were better legal proof for transactions than underhand, private contracts, but registration also cost time and money. ${ }^{13}$ The same goes for borrowers and lenders, who may have employed a notary or the aldermen only when they were unfamiliar with a particular type of contract, uncertain about its outcome, unsure about their counterparty, or when they wanted legal advice. In other cases, they may have preferred direct, private dealings with friends, relatives, and business associates. In sixteenth-century 
Antwerp, for instance, merchants commonly relied on private IOUs as backing for debts, while local cashiers developed a note circulation which must have included overdrafts for trusted clients (Puttevils 2015b; Van der Wee 1967). For Amsterdam, we know that, by the last quarter of the seventeenth century, several alternative credit options had emerged, including preprinted private loan contracts (Van Bochove and Kole 2014), wage advances from the colonial companies (Van Bochove and Van Velzen 2014), bills of exchange, suppliers' credit, and short-term borrowing against securities (Gelderblom et al. 2016).

Unlike in France, where the government capped the number of notarial offices active in any one city, in the Low Countries notaries could not operate as a closed shop, so they had to operate an entirely different business model. Until well into the nineteenth century, the license needed to work as a notary was really a diploma, an official certificate testifying to someone's ability to draft documents. Obtaining such a license meant entering a competitive business, because the authorities rarely restricted the number of licenses granted to notaries or else failed to enforce any caps imposed (Cappon 2005: 20; Nève 2005: 48). ${ }^{14}$ Consequently passing deeds remained a sideline for most notaries. As a rule, they saw only one, perhaps two or three clients a week (Table 11). Amsterdam formed the exception. The city council succeeded in keeping down numbers and local notaries sought to boost their business through specialization, say by focusing on shipping contracts or building ties to specific business communities like Sephardic or Armenian merchants. But even in Amsterdam, the average practice in 1620 or 1780 , dealing with eight clients a week, cannot have kept notaries very busy or yielded them a liv-

Table 11 The average number of deeds per notary per year, 1540-1780

\begin{tabular}{lrrrrrrr}
\hline & 1540 & 1580 & 1620 & 1660 & 1700 & 1740 & 1780 \\
\hline Antwerp & 413 & 35 & 136 & 108 & 70 & 60 & 66 \\
Ghent & & & 23 & 55 & 36 & 29 & 27 \\
Den Bosch & & & 9 & 32 & 53 & 43 & 54 \\
Utrecht & 10 & 7 & 55 & 42 & 29 & 33 & 34 \\
Leiden & & 147 & 126 & 132 & 52 & 149 & 101 \\
Amsterdam & & & 435 & 350 & 207 & 374 & 425 \\
\hline
\end{tabular}

Source: EURYI-VIDI database 
ing commensurate with their social rank and their standing as qualified legal experts. ${ }^{15}$

Unlike their Paris counterparts, notaries in the Low Countries could rarely earn a living from processing deeds alone, so they needed income from other work. They often doubled as aldermen and occupied other administrative positions, such as court clerk and bailiff, they acted as solicitors, or, in the southern Low Countries, served as priests. ${ }^{16}$ In such circumstances, one would expect them to have used the information about their clients to solicit new business by moving into active financial intermediation. This did indeed happen in Utrecht. ${ }^{17}$ At least two notaries had switched entirely to financial services by the end of the eighteenth century, one to deposit banking, and the other to securities underwriting and trading. ${ }^{18}$ In both cases, notarial and financial services developed sideby-side until the latter generated sufficient income to drop the former.

However, Utrecht was an exception. Notaries did not, as a rule, branch out into financial intermediation to supplement their income. Regressing the total number of deeds processed on the number of debt transactions per notary and per city, we found a negative non-linear relation between them. That is to say, the notaries with the best informational basis to capitalize on, that is, those with the highest number of deeds per year, had a lower proportion of financial contracts than notaries who processed few deeds and thus possessed little information with which to canvass business.

\section{Risk Pricing}

Borrowers and lenders in the Low Countries may have benefited from the segmentation of local credit markets as it facilitated the matching of a very heterogeneous supply and demand for loans. On the other hand, in the absence of the kind of information sharing practiced by Parisian notaries, it may have been more difficult to find counterparties. To explore which of these two interpretations holds, we examine the ability of creditors and debtors to adequately price risk. As a first gauge, we simply compare the average interest rate on loans registered by aldermen and notaries to the yield on bonds of the Estates of Holland. As Table 12 
Table 12 The interest rate on loans contracted by aldermen and notaries in six cities in the Low Countries, 1500-1780

\begin{tabular}{lrrrrrrrr}
\hline & 1500 & 1540 & 1580 & 1620 & 1660 & 1700 & 1740 & 1780 \\
\hline HOLLAND BILLS & & & 12.00 & 6.25 & 4.00 & 3.00 & 2.47 & 2.58 \\
& & & & & & & & \\
ALDERMEN & & 8.13 & 5.51 & 6.12 & 4.87 & 4.76 & 3.84 & 3.96 \\
Average & & 8.13 & 6.25 & 6.25 & 5.00 & 5.00 & 4.00 & 4.00 \\
Median & & 2 & 5 & 86 & 1.249 & 1.134 & 941 & 1.195 \\
Observations & & & & & & & & \\
NOTARIES & 7.21 & 6.51 & 7.13 & 6.02 & 4.73 & 4.00 & 3.41 & 3.71 \\
Average & 6.25 & 6.25 & 6.25 & 6.25 & 5.00 & 4.00 & 3.50 & 3.50 \\
Median & 362 & 387 & 221 & 800 & 548 & 336 & 416 & 292 \\
Observations & 362 & & & & & & & \\
\hline
\end{tabular}

Source: EURYI/VIDI Database

shows, the start of the seventeenth century roughly marks the beginning of the downward trend in interest rates, both public and private, due to more certainty and general economic growth along with financial innovations. The rates charged in the private markets followed market developments but they were usually higher than the yield on Holland bonds. ${ }^{19}$

To determine exactly how well risk was priced in these two market segments is impossible. There is often no information on loan repayment, for example, nor is the riskiness of a loan easy to measure because as a rule the collateral is only described and not valued. Presumably, creditors knew more about the exact value of the collateral than what is noted in our database. Nevertheless, the size of the database and the richness of information in other respects (e.g. interest rate, loan size, collateral type, and the presence of a guarantor and family relations) do allow a further examination of the relationship between return on the one hand and risk on the other. To do so, we replicate the methodology of an earlier study on price setting on the Amsterdam credit market (Gelderblom et al. 2016).

We use Ordinary Least Square (OLS) to estimate an independently pooled cross-section model for circa 7,000 credit transactions between 1620 and 1780, that is, the period in which both alderman and notaries were active. In Table 13, the first column shows the estimation results for the loans registered by aldermen, the second those of the notarial loans. The dependent variable is the interest rate premium which is the interest 
Table 13 Estimation of the output pricing of risk of loans recorded by aldermen and notaries in six cities in the Low Countries, 1620-1780

\begin{tabular}{|c|c|c|}
\hline \multirow[b]{2}{*}{ Independent variable } & \multicolumn{2}{|c|}{$\begin{array}{l}\text { Dependent variable: Interest rate } \\
\text { premium }\end{array}$} \\
\hline & Aldermen & Notaries \\
\hline Loan size (In) & $\begin{array}{r}-0.126 * * * \\
(0.017)\end{array}$ & $\begin{array}{r}-0.0824 * * * \\
(0.015)\end{array}$ \\
\hline Family & $\begin{array}{r}-0.320 * * * \\
(0.119)\end{array}$ & $\begin{array}{r}-0.401 * * * \\
(0.059)\end{array}$ \\
\hline Debtor-non-local & $\begin{array}{r}0.203 * * * \\
(0.064)\end{array}$ & $\begin{array}{r}0.0853 * * * \\
(0.028)\end{array}$ \\
\hline Debtor-foreign & $\begin{array}{r}0.346 \\
(0.238)\end{array}$ & $\begin{array}{r}0.525 * * * \\
(0.165)\end{array}$ \\
\hline Guarantor & $\begin{array}{r}0.117 \\
(0.078)\end{array}$ & $\begin{array}{r}0.119 * * * \\
(0.032)\end{array}$ \\
\hline Collateral_-real estate & $\begin{array}{r}-0.257 * * \\
(0.111)\end{array}$ & $\begin{array}{r}-0.250 * * * \\
(0.045)\end{array}$ \\
\hline Collateral-movable goods & $\begin{array}{r}0.474 * * \\
(0.202)\end{array}$ & $\begin{array}{r}0.494 * * * \\
(0.098)\end{array}$ \\
\hline Collateral_financial assets & $\begin{array}{l}-0.066 \\
(0.143)\end{array}$ & $\begin{array}{r}-0.0399 \\
(0.048)\end{array}$ \\
\hline Collateral-other & $\begin{array}{r}-0.0767 \\
(0.264)\end{array}$ & $\begin{array}{r}0.335 * * * \\
(0.116)\end{array}$ \\
\hline $\mathrm{N}$ & 2367 & 4599 \\
\hline R-sq & 0.351 & 0.370 \\
\hline adj. R-sq & 0.345 & 0.368 \\
\hline $\mathrm{F}$ & 105.2 & 79.93 \\
\hline
\end{tabular}

Note: Robust standard errors in cell below coefficient estimate Significance levels given as follows: ${ }^{* *} p<0.05, * * * p<0.01$

rate minus the risk-free rate at the time. The interest rate on bonds issued by the province of Holland is taken as the risk-free rate. The explanatory variables capture different dimensions of risk. Loan size, the kind of collateral (real estate, movable goods, financial assets, others, and general), the location of the debtor (local, non-local, and foreign), and the presence of a guarantor and family relations are the main explanatory variables. Control variables include the year, the location, and the type of contract (life annuity, redeemable annuity, obligation, and general debt notice).

The results show, first of all, that in both market segments, larger loan sizes are related to a lower interest rate premium. This makes sense as the relative importance of fixed costs involved with credit declines as the size 
of the loan increases. Moreover, larger loan sizes probably capture other aspects, like the wealth of the debtor, on which we have no other data. We do capture another well-known aspect of early modern credit markets, that is, the impact of the social and geographical distance between creditors and debtors on loan terms. As expected, a family relationship between the contracting parties is related to a cut in the interest rate premium. Conversely, non-local and foreigner borrowers paid a premium, although this effect is statistically insignificant for the foreigners, only three, we identified in the aldermen's registers. The presence of a guarantor for a creditor to call upon in case of default seems to be related to a small increase in the risk premium, at least with notarial loans. This effect, though not very strong, is worth pondering as a guarantor should increase the security of a loan, ceteris paribus. In this case, the increased premium seems to suggest that the debtor needed this additional safeguard to obtain a loan in the first place. The clear pattern of the regression results also suggests that aldermen and notaries were passive recorders of loans, not active intermediaries linking creditors to debtors and vice versa. The contracting parties appear to have agreed on conditions before formalizing them, though that does not, of course, exclude the possibility of them getting advice on contract details from a legal expert such as the notary.

When looking at the impact of different types of collateral, it is important to remember that our reference group is the general mortgage ("person and goods'). Securing a loan with just this kind of collateral might indicate that the creditor knew and trusted the debtor and/or estimated the debtor's assets to be of enough value to cover the loan in case of default. But it could also mean that the debtor actually had nothing specific to offer as collateral, indicating a rather risky loan. It is hard to distinguish between these two possibilities. However, since we control for family relations, the presence of a guarantor, and the location of the debtor, one would expect the pledging of a specific kind of collateral to reduce the risk for creditors. This is indeed what we find for the safest type of collateral, real estate: the premium goes down. Movable goods, however, are priced as less secure than the very general collateral. This is most likely due to them being of uncertain value and hard to control, especially if debtors held on to them. Finally, the use of financial assets as collateral does not lead to a lower premium. These assets were supposedly 
easy to price and highly liquid, and therefore a very attractive loan collateral (Gelderblom and Jonker 2004). But many financial assets that were used as collateral here were actually not highly liquid VOC (Dutch East India Company) shares or government bonds, but rather parts in smaller shipping companies or deeds of private loans.

For all the reasons mentioned above, we have to be careful not to read too much into these results. There is little doubt, however, that the parties who registered loans with the aldermen and notaries were able to judge a loan's risk and adjusted the allocation and pricing of credit accordingly.

\section{Conclusion}

By the mid-sixteenth century, the unification of the Netherlands under Burgundian and Habsburg rule had created an institutional framework for private and public credit markets that was remarkably similar across the realm. Key features were the emergence of a funded public debt; a system for registering private annuities, mortgages, and other medium- and longterm loans; and the formal acceptance of debt and equity contracts drafted by notaries as legally equal to those passed before aldermen. In the major commercial cities, Antwerp and Amsterdam in particular, local officials supported an even wider range of negotiable instruments, notably bills of exchanges and bills obligatory, and they regulated the work of various financial intermediaries, including brokers, moneychangers, and cashiers.

In this chapter, we explored the functioning of two adjacent market segments in various cities in the Low Countries: the loans recorded by aldermen and notaries between 1500 and 1780 . We find that notaries and aldermen were widely used to register loans, yet neither obtained a commanding position in local credit supply. Since real estate transactions had to be publicly registered, the aldermen were central in the mortgage market, but of only secondary importance in the wider loan market, where a large variety of other credit forms existed. Notaries processed a large volume of debt secured on collateral other than real estate, but they played no role in either the marketing of public debt or in the mortgage market. Moreover, the obligation to publicly register real estate transactions robbed them of the informational advantages which Parisian 
notaries possessed, while the open entry to the notarial profession prevented them from operating as a closed shop and capitalizing on any such advantages they might have had. These findings highlight the degree to which subtle regulatory differences profoundly affected the dynamics of financial market evolution.

\section{Notes}

1. Cf. the distinction made by Schnapper (1956) between the rente as a counterclaim created to finance the transfer of a property, and the constitution of a rente as a means to obtain ready cash on the collateral of a house or a piece of land.

2. Following the same logic, we did collect life annuities, but the number of these self-extinguishing cash loans was very limited, i.e. 230 across the entire sample.

3. Notably in Holland, the market for these kustingen was very large. For instance, in Amsterdam the number of registered kustingen rose from 150 to 200 per year in the late sixteenth century to 1500 in 1620 and 900 in 1660 - an upward trend related to the city's very rapid expansion during the Golden Age. By 1700, the number had dropped to 300 (EURYI/VIDI database, data drawn from ACA, Archive 5063, Register van Schepenkennisen 1594-1595. Archive 5065, Register van Rentebrieven en Transporten van los-en liffrenten, 1580, 1620, 1660, 1700, 1740, 1780).

4. We know from the work of Soly, Dambruyne, and Hanus that the number of recorded transfers in Antwerp, Ghent, and Den Bosch, respectively, was very large in the sixteenth century. A small sample of our own, for the aldermen of Den Bosch in 1580 and 1620, revealed 173 and 113 transfers of annuities per year, respectively. SDB, Archive 5.1, Bosch Protocol, 1580, 1620.

5. Table 3 presents a lower bound estimate of this very gradual process, since, to avoid duplication with the aldermen, we did not collect transactions secured on real estate processed by the notaries.

6. In our tabulation, the general mortgage includes 'persoon en goed' and 'persoon'; real estate includes: houses, land, workshops, mills; financial assets include bonds, shares, and loans; other includes: merchandise, ships, unspecified 'goods', collective goods (e.g. from inheritance or communal institution), and any other kind of collateral. 
7. We follow Soly (1977) in categorizing a very broad group of artisans, service providers, and workers as craftsmen and laborers. It should be noted however that only a few dozen of these have job titles such as 'arbeider', 'dienstbode', and 'onvrije schipman' that suggest they were indeed working for wages, instead of being self-employed. Thus, the vast majority of the debtors and creditors that fall under this category may have belonged to the urban middling groups.

8. In 1620 , we recorded 169 loans $(11.7 \%)$ of less than 100 guilders, in 1700 , there were 74 loans $(3.7 \%)$ and in 1780 only $10(0.6 \%)$.

9. Since we filtered out the direct mortgaging of property on purchase, the low percentage of loans to buy real estate fails to surprise.

10. In 703 of the 1,240 aldermen contracts with a gender difference between parties, $57 \%$ of the women were widows; in 884 of the 1,605 notarial contracts, $55 \%$ of the women were widows. The vast majority of these widows were creditors, not debtors.

11. Cf. Van Bochove and Kole (2014), p. 53, who note that the private, preprinted contracts that were used in Amsterdam in the second half of the seventeenth century sometimes contained a clause in which the debtor agreed to formally register the loan with the notary if so desired by the creditor.

12. We can be brief about a potential fourth function of the notaries, the pooling of household wealth to fund government expenditure. Unlike in France, notaries in the Low Countries played no role whatsoever in the placement of public loans (Gelderblom and Jonker 2011, 2014).

13. Cf. Van Hoof, Generale zekerheidsrechten 108-109 quoting Pos, Hypotheek op onroerend goed 161, about merchants generally lacking the time to formalize claims.

14. Cf. also Sprenger, 'Notariaat', 128, 130; and for a rare instance of restrictions in Breda, idem, 124.

15. Roes, Goede, afvallige notaris 7, 9, 13, 14, on the social status of notaries in Gelderland.

16. Roes, Goede, afvallige notaris, 7, 9; Sprenger, 'Notariaat', 127, and 125, mentioning one seventeenth-century case of a surgeon-notary.

17. Van Bochove (2013). In Utrecht's notarial protocols, we found 218 transfers of private and public bonds in 1740, and another 256 in 1780. With 17 and 19 transfers in 1660 and 1700, respectively, this specialization seems much less pronounced in the seventeenth century (HUA, Archive 34-4, Notariële archieven stad Utrecht). In the eighteenth cen- 
tury, notaries in Den Bosch also recorded several dozens of transfers per year: 10 in 1700; 33 in 1740; 33 in 1780 (SDB, Archive 9.1, Notarieel Archief, 1660, 1700, 1740, 1780).

18. That is, respectively, Jan Kol, a cashier and fledgling deposit banker, and D.W. van Vloten, an underwriter for Hope \& Co.'s foreign loans (Van Bochove 2013).

19. There is a possibly very important technicality here: from about 1680 onward public bond holders paid a withholding tax on Holland's bonds which stood at $1.5 \%$ from the early seventeenth century onward. It is quite conceivable that loans that were formally registered also fell under this tax regime, which would imply that the yield on these private loans was actually on par with the public loans.

\section{References}

Boone, M., K. Davids, and P. Janssens, eds. 2003. Urban Public Debts. Urban Governments and the Market for Annuities in Western Europe (14th-18th Centuries). Turnhout: Brepols.

Bordo, M.D., A. Redish, and H. Rockoff. 2015. Why Didn't Canada have a Banking Crisis in 2008 (or in 1930, or 1907, or ...)? Economic History Review 68 (1): 218-243.

Calomiris, C.W., and S.H. Haber. 2014. Fragile by Design. The Political Origins of Banking Crises \& Scarce Credit. Princeton: Princeton University Press.

Cappon, C.M. 2005. Het notariaat in de late Middeleeuwen ( $\pm 1250- \pm 1540$ ). In Het notariaat in de Lage Landen ( $\pm 1250-1842)$, ed. A.F. Gehlen and P.L. Nève, vol. 2, 1-30. Deventer: Kluwer.

Carlos, A.M., and L. Neal. 2011. Amsterdam and London as Financial Centers in the Eighteenth Century. Financial History Review 18: 21-46.

Dambruyne, J. 1988. De 17de-eeuwse schepenregisters en de rente- en immobiliëntransacties te Gent: enkele beschouwingen. Handelingen der Maatschappij voor geschiedenis en oudheidkkunde te Gent 42: 153-182.

- 2001. Mensen en centen: Het 16de-eeuwse Gent in demografisch en economisch perspectief. Ghent: Maatschappij voor Geschiedenis en Oudheidkunde.

Des Marez, G. 1901. La lettre de foire a Ypres au XIIIe siècle, contribution à l'étude des papiers de crédit. Brussels: H. Lamertin.

Fohlin, C. 1999. Universal Banking in Pre-World War I Germany: Model or Myth. Explorations in Economic History 36: 305-343. 
Gelderblom, O. 2013. Cities of Commerce: The Institutional Foundations of International Trade in the Low Countries, 1250-1650. Princeton: Princeton University Press.

Gelderblom, O., and J.P.B. Jonker. 2004. Completing a Financial Revolution: The Finance of the Dutch East India Trade and the Rise of the Amsterdam Capital Market, 1595-1612. Journal of Economic History 64: 641-672.

- 2011. Public Finance and Economic Growth: The Case of Holland in the Seventeenth Century. The Journal of Economic History 71 (1): 1-39.

- 2014. The Low Countries. In The Cambridge History of Capitalism, Vol. 1: The Rise of Capitalism, ed. L. Neal and J.G. Williamson, 314-356. Cambridge: Cambridge University Press.

Gelderblom, O., J.P.B. Jonker, and C.J.M. Kool. 2016. Direct Finance in the Dutch Golden Age. Economic History Review 69 (4): 1178-1198.

Hanus, J. 2009. Een efficiënte pre-industriële kapitaalmarkt? Het vroeg zestiende-eeuwse 's-Hertogenbosch als voorbeeld. Tijdschrift voor Sociale en Economische Geschiedenis 3: 82-113.

Hoffman, P.T., G. Postel-Vinay, and J.-L. Rosenthal. 2000. Priceless Markets. In The Political Economy of Credit in Paris, 1660-1870. Chicago: University of Chicago Press.

—_. 2017 "Priceless Markets II: Time and Space", unpublished mimeo. http://people.hss.caltech.edu/ -jlr/events/2013-HPVR.pdf.

Levine, R. 1997. Financial Development and Economic Growth: Views and Agenda. Journal of Economic Literature 35: 688-726.

- 2002. Bank-Based or Market-Based Financial Systems: Which Is Better? Journal of Financial Intermediation 11: 398-428.

Merton, R.C., and Z. Bodie. 1995. A Conceptual Framework for Analyzing the Financial Environment. In The Global Financial System, a Functional Perspective, ed. D.B. Crane et al., 3-32. Boston: Harvard Business School.

Munro, J.H. 2003. The Medieval Origins of the Financial Revolution: Usury, Rentes, and Negotiablity. The International History Review 25 (3): 505-562.

Nève, P.L. 2005. Het notariaat in de Habsburgse Nederlanden. In Het notariaat in de Lage Landen ( \pm 1250-1842), ed. A.F. Gehlen and P.L. Nève, vol. 2, 37-76. Deventer: Kluwer.

Petram, L.O. 2014. The World's First Stock Exchange. New York: Columbia University Press.

Puttevils, J. 2015a. Merchants and Trading in the Sixteenth Century: The Golden Age of Antwerp. London: Pickering \& Chatto.

- 2015b. Tweaking Financial Instruments: Bills Obligatory in SixteenthCentury Antwerp. Financial History Review 22 (3): 337-361. 
Rousseau, P.L., and R. Sylla. 2007. Financial Systems, Economic Growth, and Globalization. In Globalization in Historical Perspective, ed. M.D. Bordo, A.M. Taylor, and J.G. Williamson, 373-415. Chicago: University of Chicago Press.

Schnapper, B. 1956. Les rentes au XVIe siècle. Histoire d'un instrument de crédit. Paris: Université de Paris.

Soly, H. 1974. De schepenregisters als bron voor de conjunctuurgeschiedenis van Zuid- en Noordnederlandse steden in het Ancien Régime. Tijdschrift voor Geschiedenis 87: 521-544.

1977. Urbanisme en kapitalisme te Antwerpen in de 16de eeuw: de stedebouwkundige en industriële ondernemingen van Gilbert van Schoonbeke. Brussel: Gemeentekrediet.

Sylla, R. 1991. The Role of Banks. In Patterns of European Industrialization, the Nineteenth Century, ed. R. Sylla and G. Toniolo, 45-63. London: Routledge. Sylla, R. 2002. Financial Systems and Economic Modernization. The Journal of Economic History 62: 277-292.

van Bochove, C. 2013. Configuring Financial Markets in Preindustrial Europe. The Journal of Economic History 73 (1): 247-274.

van Bochove, C., and H. Kole. 2014. Uncovering Private Credit Markets: Amsterdam, 1660-1809. The Low Countries Journal of Social and Economic History 11 (3): 39-72.

van Bochove, C., and T. van Velzen. 2014. Loans to Salaried Employees: The

Case of the Dutch East India Company, 1602-1794. European Review of Economic History 18 (1): 19-38.

van Bochove, C., H. Deneweth, and C.J. Zuijderduijn. 2015. Real Estate and Mortgage Finance in England and the Low Countries, 1300-1800. Continuity and Change 30: 9-38.

van der Heijden, Manon. 2006. Geldschieters van de stad. Financiële relaties tussen stad, burgers en overheden 1550-1650. Amsterdam: Bert Bakker.

van der Wee, H. 1967. Anvers et les innovations de la technique financière aux XVIe et XVIIe siècles. Annales ESC 22 (5): 1067-1089.

van Hoof, V.J.H. 2015. Generale zekerheidsrechten in rechtshistorisch perspectief. Deventer: Wolters Kluwer.

Zuijderduijn, C.J. 2008. Conjunctuur in laatmiddeleeuws Haarlem. Schepenregisters als bron voor de economische ontwikkeling van een Hollandse stad. Tijdschrift Holland 40 (1): 3-17.

. 2009. Medieval Capital Markets, Markets for Renten, State Formation and Private Investment in Holland (1300-1550). Leyden: Brill. 